\title{
Siwalik basin of Arunachal Himalaya, India: a case study
}

\author{
P.K. Das and H. Baruah \\ Department of Geological Sciences, \\ Gauhati University, Guwahati 781 014, India.
}

\section{ABSTRACT}

The Siwalik basin of Arunachal Himalaya is a part of the Himalayan foreland. Due to continental collision between Indian and Eurasian plates, the Himalayan mountain system experienced intense uplift and erosion and as a result, a large amount of siliciclastic sediments accumulated within the foreland and a remnant ocean basin (which was commonly known as foredeep) was developed during Eocene. Moreover, the sediments were deposited by a large river draining the uplifted Himalayan belt during late Neogene. From the pattern of lithofacies, the river may be envisaged as braided type and was a bit shallow relative to its width, floored by bars and channels of low sinuosity and with a bed load of sand and pebbly sediments.

These sediments present in the Arunachal foothills are bounded by the Brahmaputra Alluviums in the south and the Gondwana belt in the north and, by a system of frontal faults and the Main Boundary Fault, respectively. The sediments are mostly of molasse type (Upper Tertiary sediments), of different sedimentary facies present in the form of thick accumulation of multilateral and multistoried bodies. Moreover, the depositional basin suffered from some tectonic disturbances for which open folds and many reverse faults were formed.

With the formation of foredeep infront of the Himalaya, a reversal of slope towards north-west took place in post-Barail times and during the later part of the Tertiary, the Himalayan and the Upper Assam basin were continuous below the Brahmaputra Alluviums as evidenced by field and laboratory observations.

From these observations, it is seen that the Siwalik basin of Arunachal Himalaya has close resemblance with the Tertiary basin (Neogene basin) of Upper Assam rather than the Siwalik basin of western Himalaya and thus, this basin may be treated as a separate basin which may be renamed as "Tertiary basin of Arunachal'.

\section{INTRODUCTION}

The great Himalayan mountain belt has been a point of curiosity for the workers world wide for many of its characteristics. A sort of obsession had developed to know more about it despite accessibility posing a major hindrance in the path of pursuit. The dimensions of this belt is so large that a spatial variation in all aspects of geology like lithology, palaeontology, structures, etc. is seen. This is evident even from the most accessible zone of the Himalaya, i.e. the foothills. Even though the name 'Siwalik' shadows the terrain of the Himalayan foreland, quite a lot of variations are seen both in and out.
For facilitating description of the stratigraphy and structure of the Himalayan foothills, it has been divided into various sectors (Fig.1). This endeavour is concerned with Arunachal Himalaya. Accessibility being very poor in this region, the pursuit was within a narrow belt, which buoyed up by whatever previous literature is available regarding this terrain has been tried to come out to a tentative conclusion on a broader scale (Fig. 2).

The Siwalik basin of Arunachal Himalaya is a part of the Himalayan foreland. The continental collision between India and Asia (Dewey et al., 1989; Harrison et al., 1992) made the Himalayan chain 


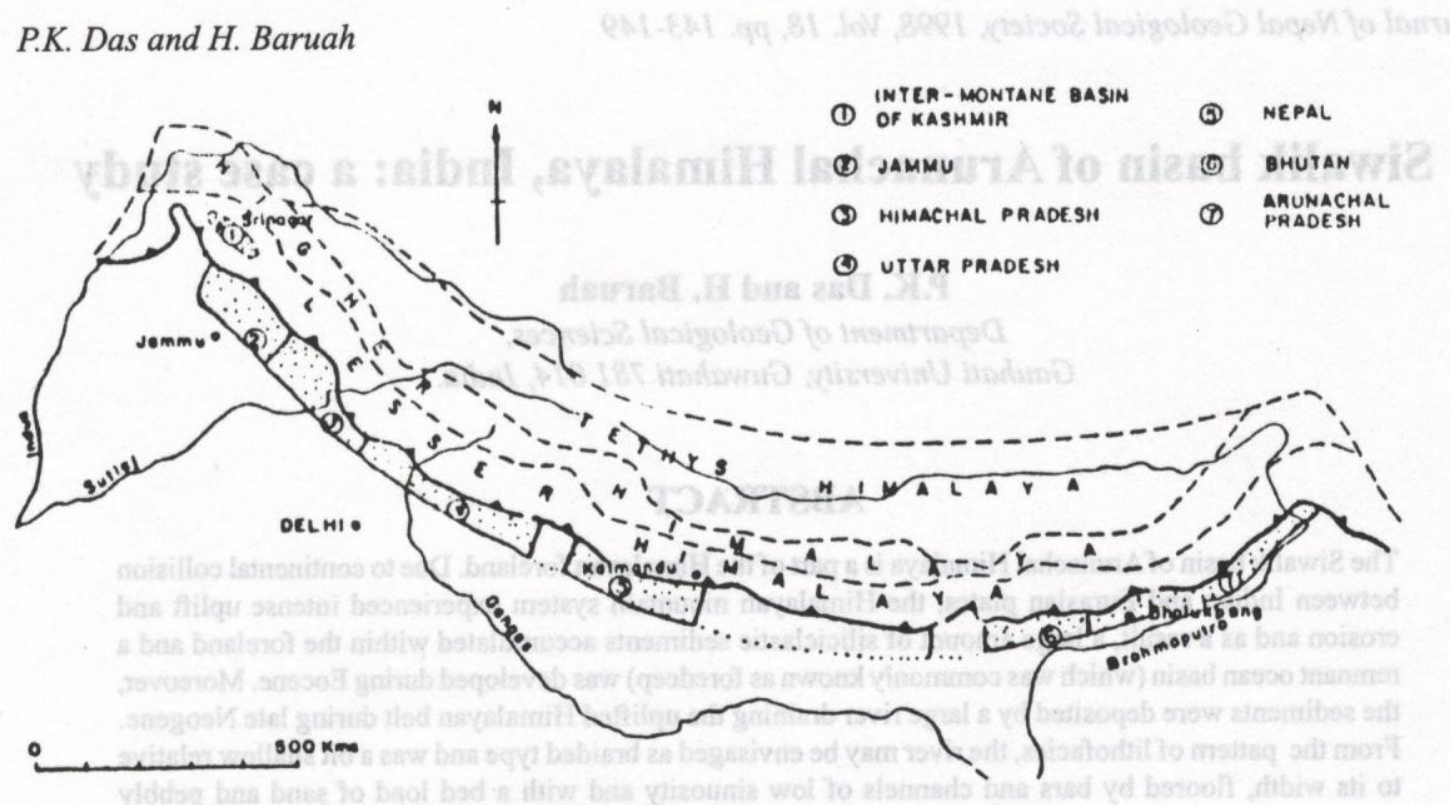

Fig. 1: Index map showing the areas of the Himalayan foothills.

experience intense uplift and erosion and, as a result, a large amount of siliciclastic sediments accumulated in the foreland. Therefore, the Himalayan foreland is an area of active sedimentation in which the sediments eroded and transported from the Himalayan uplift have accumulated in the basin. The extensive apron of sedimentary sequences are deformed in the northern part and include the foothills rising to the north of the Indo-Gangetic and the Brahmaputra plains. The width of the Himalayan orogenic belt varies from $300 \mathrm{~km}$ to $400 \mathrm{~km}$ (Gansser, 1964). Plate motion and consequent continuous involvement of the basin in crustal shortening are factors which complicate estimation of this basin dimension. Lyon-Caen and Molnar (1985) said that the foreland basin was a steady state feature and it was lying in front of the Himalaya. The width of the basin, therefore, was dependent on the flexural rigidity of the Indian plate. However, the development of foreland was formed by the tectonic activities of the Himalayan orogen. The Himalayan collisional orogenic belt represents a complex zone of uplift which is composed of at least five lithotectonic provinces. The Himalayan foreland belt is the southernmost of these five provinces and consists of detrital sedimentary rocks which were derived from the litho-tectonic provinces lying to the north. Similar observation was made in Ladakh molasse by Sati et al. (1996).

\section{GEOLOGY OF THE BASIN}

The Siwalik belt is the southernmost lithotectonic belt of Arunachal Himalaya and is delineated against the Brahmaputra Alluviums in the south and the Gondwana belt in the north by a system of frontal faults and the Main Boundary Fault, respectively. This belt is in direct continuation with that of the Bhutan Himalaya in the west and extends approximately ENE-WSW to NE-SW through the Arunachal foothills. Between the Sessri and Dibang river in the east, this belt is absent. This gap is known as 'Sessri-Dibang Gap' (Singh and Chowdhary, 1990). The general stratigraphic column starts with the Precambrian metasediments and granites followed by thick limestone-shale-quartzite alternations, Gondwanas (continental and marine) and traps and, the Tertiary sequences. An attempt is made to compare and contrast these units with the rest of the Siwaliks. The sedimentological studies of the Tertiary rocks (Siwaliks) of the Arunachal foothills show the distinct impacts of tectonism on their sedimentation pattern (Das, 1991, 1995).

The Siwaliks belt comprises predominantly the rocks belonging to the Siwalik Group, which on the basis of lithological characteristics and associations, is divisible into: (1) Lower Siwaliks, (2) Middle Siwaliks and (3) Upper Siwaliks (Fig. 3). 


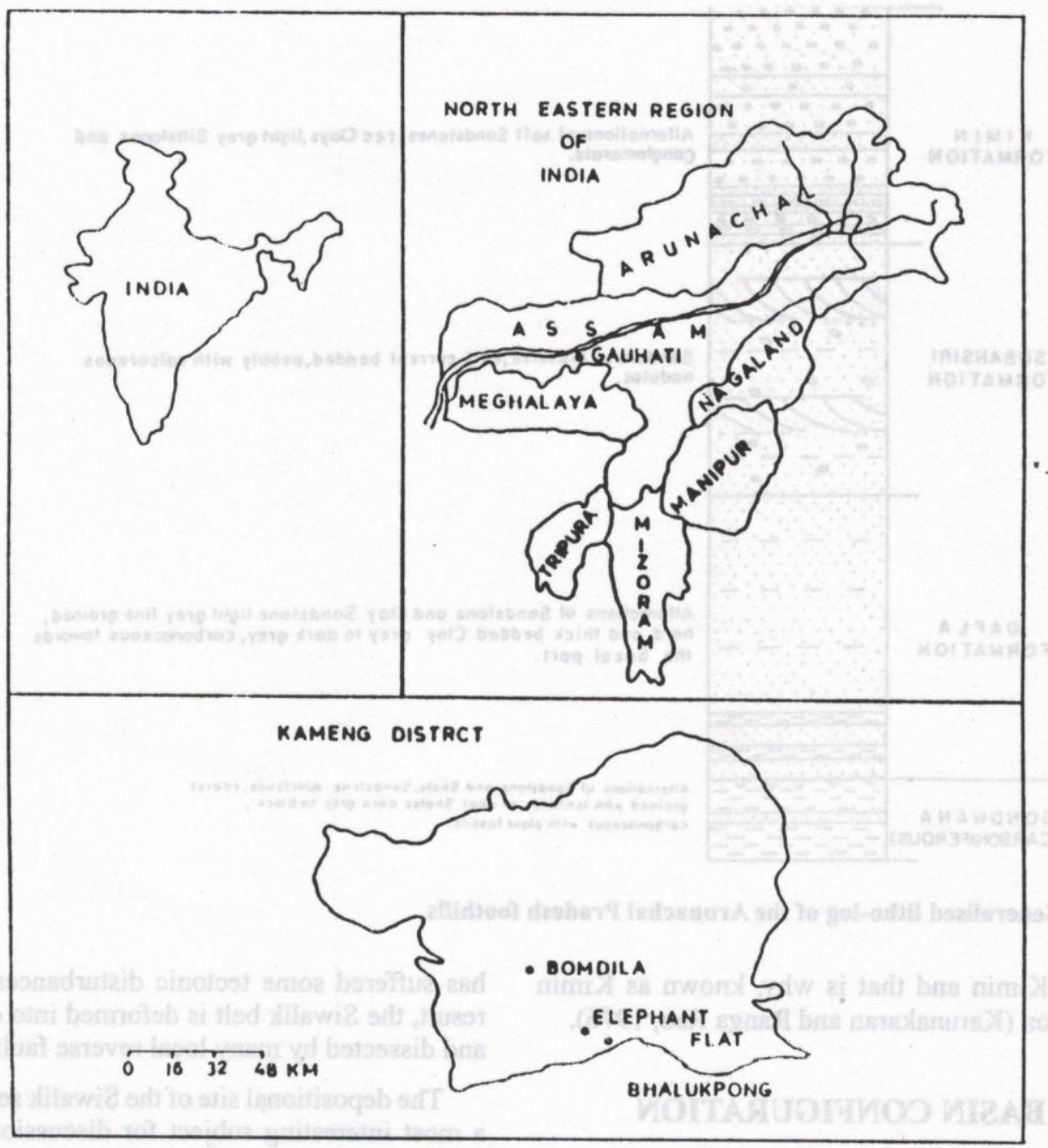

Fig. 2: Location map of the study area.

The Lower Siwaliks are represented by dominantly fine to medium grained sandstones and siltstones, interbedded with shale and clay. Sandstones are poorly micaceous, quartzose and bear resemblance to the Gondwana sandstones. Well preserved leaf impressions and some microfossils (?) are recorded. The Lower Siwaliks are named as Dafla Formation by Karunakaran and Ranga Rao (1976).

The Middle Siwaliks are composed of medium to coarse grey coloured sandstones with pebbles and pebble layers. Current-beddings, coal (lignite) pockets, irregular calcareous concretions, carbonised-silicified wood fragments are the main features. The Middle Siwaliks are named as Subansiri Formation (Karunakaran and Ranga Rao, 1976).

The Upper Siwaliks consist mainly of pebblebeds with interbands of loose sandstone beds and are of variable sizes of different lithounits. Preferred orientations of the coarser clasts are lost from lower to upper horizons. Interbands of clay and pellets of carbonaceous shale (probably derived from the underlying Gondwana sediments) are seen in between. The Upper Siwaliks are well-exposed 


\section{P.K. Das and H. Baruah}

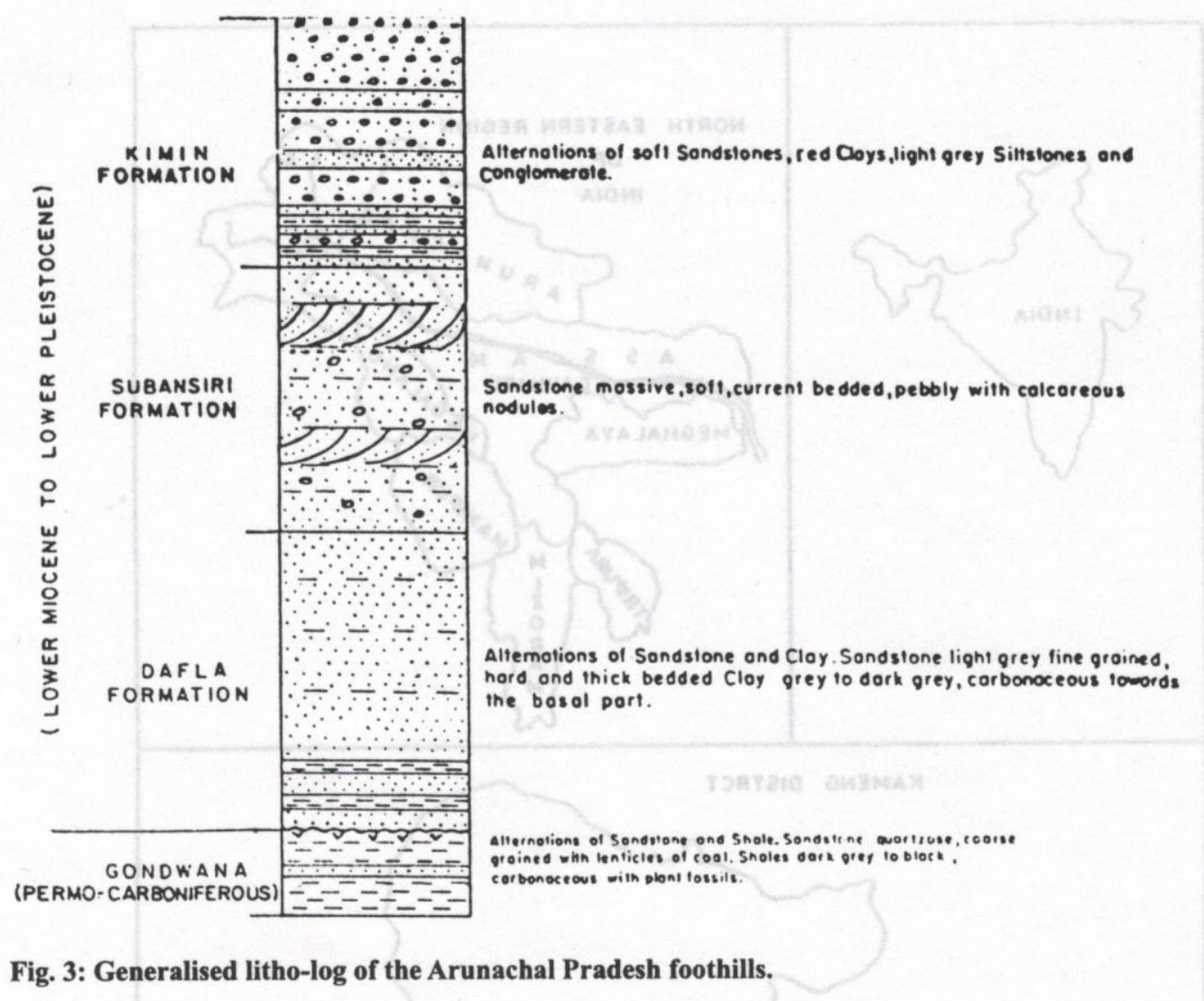

around Kimin and that is why, known as Kimin Formation (Karunakaran and Ranga Rao, 1976).

\section{BASIN CONFIGURATION}

The Siwalik basin of Arunachal Himalaya is mostly characterised by molasse deposit of different sedimentary facies. Within the Siwalik basin, there is yet another remarkable event seen in the form of thick accumulations of multistoried sand complexes from Eocene to Pleistocene time. These mostly fluvial type sandstone bodies are useful for predicting channel type and behaviour (Allen, 1983; Friend et al., 1979). From the field studies, it was seen that the sediments are extensive multilateral multistoried bodies. Moreover, the vast thickness and lateral extent of the Siwalik Group is in itself a pointer towards complex sedimentation patterns in the basin. The marked variability of the geometry of sandbodies of the Siwalik Group is reflective of variability in channel behaviour and type. The basin has suffered some tectonic disturbances and as a result, the Siwalik belt is deformed into open folds and dissected by many local reverse faults.

The depositional site of the Siwalik sediments is a most interesting subject for discussion. Pilgrim (1919) delivered his view about the existence of river Siwalik. Johnson et al. (1985) favoured the existence of a Siwalik River of Pilgrim. Pascoe (1919) also supported the view of Pilgrim; but he renamed this river as 'Indo-Brahm' which flowed from Assam (Arunachal) to Punjab. According to Aiyenger and Krishnan (1940) there existed a gulf sort of basin where sediments were deposited and this basin was formed by the breaking up of the Eocene sea in the Northwest of India.

Edward Suess argued that the Siwalik sediments were deposited in a depression which was known as 'Foredeep' in front of the Himalaya. This view was made based upon the geodetic observations, (Agarwal, 1959). According to Pande and Saxena (1968) there existed a Lower Tertiary sea or, Lower Tertiary basin 
all along the foothill regions from Assam (Arunachal) to Kashmir. Gill (1951) mentioned about the Siwalik deposition as fluviatile origin but he doubted the existence of a river as suggested by Pilgrim (1919) and Pascoe (1919). But Gansser (1964) remarked that except to the younger conglomerate the entire Siwalik Group is the result of an intricate system of longitudinal rivers. Satsangi and Datta (1971) mentioned four different environments of deposition namely, the piedmont, outwash plains, channel and flood plains and lacustrine.

It is seen that the process of erosion and deposition of sediments can be compared with that of existing river systems of the Himalaya like the Ganges and Brahmaputra. These are the braided rivers coming from the Himalaya. These rivers are characterised by wide channels of changing position, and rapid and continuous shifting of the sediments. Consequently, an individual unit may have a width comprised between 5 and $8 \mathrm{~km}$. Their length may commonly range from $10 \mathrm{~s}$ to $100 \mathrm{~s} \mathrm{~km}$. The thickness of an individual unit ranges from several decimeters to 30 meters. The width-depth ratio is high. Area occupied by braided rivers may be very wide and coalescing bars and sandflats will result in a laterally continuous and extensive sand sheet.

On account of close resemblance between the materials constituting the modern alluvia of rivers and the Siwalik sediments, Wadia (1961) suggested that they were chiefly water-worn debris of the granitic cores of the central Himalaya deposited in the long and broad valley of the "Siwalik river".

Graham et al. (1976) considered it to be a part of a linked sedimentary system: Himalayan uplifts-Siwalik basin (Molasse)-deltaic (Ganga Brahmaputra-Submarine fan (Bengal-Nicobar fans). These Siwalik sediments were derived from orogenic highlands formed by the continental collision.

Continuity of the Siwalik basin of Arunachal Himalaya with the Siwalik basin of western Himalaya is found doubtful after field and laboratory observations (Karunakaran and Ranga Rao, 1976). But the present authors have found the continuity of the Siwalik basin of Arunachal Himalaya along with the Tertiary basin of Upper Assam.

Raju (1968) mentioned that the two basins were perhaps continuous below the Brahmaputra
Alluviums. The whole belt has become a craton by mid-Miocene times when there was block faulting and a frontal foredeep developed in which the Siwalik sediments were deposited derived mostly from the newly risen Himalayan mountain chain, this was connected with the Upper Assam foredeep (Murthy, 1970).

From the above remarks and from the following observations, the author has passed a view that there was a connection between the Siwalik basin of Arunachal Himalaya and the Tertiary basin of Upper Assam. With the formation of foredeep infront of the Himalaya a reversal of slope towards north-west took place in post-Barail times and during the later part of the Tertiary, the Himalayan and Upper Assam basins were continuous.

The field observations of the Siwalik Group show that the lithological characters of these rocks have close resemblance with the Tertiary rocks of Upper Assam, i.e. Bokabil sandstones with Lower Siwalik sandstones, Tipam sandstones with Middle Siwalik sandstones and Dihing pebble beds with Upper Siwalik pebble beds.

The heavy mineral suits of the Siwalik sediments of Arunachal Himalaya are almost same with the heavy mineral suites of the Tertiary sediments of Upper Assam. Moreover, the lignite present in the Middle Siwalik sandstones has marked resemblance with the lignite found in the Tipam sandstones of Upper Assam (Das, 1972). Probably there was a connection between depositional sites of both lignites. It indicates the presence of some organic matters within the sediments.

The Dafla green claystones and carbonaceous shale bed association does not show any similarities with the Lower Siwaliks. The latter is predominantly a red bed association indicating their deposition in an oxidising environment in the western part of the Himalaya while a general reducing environment is suggested by the green coloured claystones with abundantly preserved plant material in Dafla. These are characters of the Bokabil Formation of Assam.

In general, the faunal content of the Siwaliks of Arunachal Himalaya is poor compared to the rich vertebrate fauna of Siwaliks in the western Himalaya. Whereas the fossils in Arunachal are mostly restricted to micro and megaflora and a lone vertebrate fossil in the Subansiri Formation. 


\section{CORRELATION}

Based on the above cited data, the Siwalik basin of Arunachal can broadly be correlated with that of Assam.

\begin{tabular}{|c|c|}
\hline ARUNACHAL & ASSAM \\
\hline Kimin & Dihing \\
Subansiri & Tipam \\
Dafla & Bokabil \\
\hline
\end{tabular}

\section{CONCLUSIONS}

The Siwalik basin of Arunachal Himalaya is an important part of the Himalayan foreland. Following the continental collision between India and Asia, the Himalayan chain experienced intense uplift and erosion and as a result a large amount of terrestrial sediments accumulated within this foreland basin and remnant ocean which was developed from Eocene time. These sediments were derived from the Higher Himalayan rocks and transported to the basin. However, the upper portion of the sediments was carried by a large river draining the uplifted Himalayan belt and was deposited in the foredeep fresh water basin which was formed due to upliftment of the Himalaya during Neogene time from Eocene ocean basin. Moreover, some sediments (mostly pebbles) were deposited within the river bed. The seasonal variation of deposition was observed mostly within younger sediments of the Kimin Formation. As the sediments of this basin have less resemblance with the sediments of the western Himalaya, therefore this basin may be treated as the separate basin. Moreover, evidences shown that this basin has close connection with the upper Tertiary basin of Upper Assam. So this basin may be renamed as Tertiary 'Arunachal basin'.

\section{ACKNOWLEDGEMENTS}

The authors offer thanks to the Head of the Department of Geological Sciences for laboratory facilities. The first author is also grateful to the Wadia Institute of Himalayan Geology for financial support during field work.

\section{REFERENCES}

Agarwal, G.C., 1959, Stratigraphy and sedimentation of the Himalayan foothills with regard to the Oil prospects in the gangetic valley. Proc. ONGC, Tech. Publ., pp. 47-51.

Alyengar, N.K. and Krishnan, M.S., 1940, Did the Indo-Brahma or Siwalik river exist? Rec. Geol. Surv. Ind., v. 75, pp. 9-13.

Allen, J.R.L., 1983, Studies in fluviatile sedimentation: bars, bar complexes and sandstone sheets (low sinuosity braided streams) in the Brownstone (L. Devonian), Welsh Borders. Sed. Geol., v. 33, pp. 237-293.

Das, P.K., 1972, A note on the age and depositional conditions of Subansiri Lignite, NEFA Himalaya. Quart. Jour. Geol. Min. Met. Soc. Ind., v. 44(2), pp. 155-158.

Das, P.K., 1991, Tectonic evolution of the Arunachal Himalaya Jour. Assam Sc. Soc., v. 33, pp. 66-70.

Das, P.K., 1995, Petrography of the Upper Tertiary Sandstones of same parts of Arunachal Pradesh. Him. Geol., v. 6(1), pp. 23-29.

Dewey, J.F., Cande, S. and Pitman, W.C., 1989, Tectonic evolution of the Indian/Eurasian collision zone, Eclogal Geological Helveticae, v. 82, pp. 717-734.

Friend, P.F., Slater, M.J. and Williams, R.C. 1979, Vertical and lateral building of river sandstone bodies, Ebro Basin, Spain, Jour. Geol. Soc. London, v. 136, pp. 39-46.

Gansser, A., 1964, Geology of the Himalaya. Interscience Publishers, London, $289 \mathrm{p}$.

Gill, W.D., 1951, The stratigraphy of the Siwalik series in the Northern Potwar, Pakistan. Quart. Jour. Geol. Soc. London, v. 107, pp. 375-394.

Graham, S.A., Dickinson, W.R. and Ingersoll, R.V., 1976, Himalayan Bengal Model for Flysch dispersal in the Appalachian-Quachita System. Geol. Soc. Am. Bull., v. 86, pp. 97-116.

Harrison, T.M., Copeland, P., Kide, W.S. and Yin, A., 1992, Rising Tibet. Science, v. 255, pp. 1663-1670.

Johnson, N.B., Stix, J., Tauxe, L., Cerveny, P.L. and Tarirkheli, RAK, 1985, Palaeomagnetic Chronology, fluvial processes, and tectonic implications of the Siwalik deposits near Chinji village, Pakistan, Jour. Geol., v. 93, pp. 27-40.

Karunakaran, C. and Ranga Rao, A., 1976, Status of exploration for hydrocarbons to stratigraphy and structure Him. Geol. Sem. Section III, pp. 1-71.

Lyon Caen, H. and Molnar, P.. 1985, Gravity anomalies, Flexure of the Indian Plate and the structure, support and evolution of the Himalaya and Ganga basin, Tectonics, v. 4(6), pp. 513-538. 
Siwalik basin of Arunachal Himalaya, India: a case study

Murthy, A.V.N., 1970, Tectonic and mafic igneous activity in North-east India in relation to Upper mantle. Proc. 2nd Symp. Upp. Mant. Proj., v. 4, pp. 296-299.

Pascoe, E.H., 1919, The early history of the Indus, Ganges and the Brahmaputra. Quart. Jour. Geol. Soc. London, v. LXXV, pp. 138-155.

Pilgrim, G., 1919, Suggestions concerning the history of the drainage of Northern India arising out of a study of the Boulder conglomerate. Jour. As. Soc. Beng. N.S., v. XV, pp. 81-101.

Raju,A.T.R., 1968, Geological evolution of Assam-Cambay Tertiary basins, India. Bull. Am. Assoc. Petrol. Geol., v. 52(12), pp. 92-98.
Sati, D., Nanda, A.C. and Mishra, G.S., 1996, Deformational structures in Ladakh Molasse and their significance in interpreting the collission scenario. Jour. Geol. Soc. India, v. 47, pp. 625-628.

Satsangi, P.P. and Dutta, A.K., 1971, Advance in the stratigraphy of the Siwalik rocks. Rec. Geol. Surv. India, v. 101, Part 2, pp. 193-208.

Singh, S. and Chowdhary, P.K., 1990, An outline of the Geological Framework of the Arunachal Himalaya. Him. Geol., v. 1(2), pp. 189-197.

Wadia, D.N., 1961, Geology of India. Mc Millan Co. Ltd., $536 \mathrm{p}$. 